\title{
A simplified model for linear correlation between annual yield and DNI for parabolic trough collectors
}

Ahlgren, Benjamin; Tian, Zhiyong; Perers, Bengt; Dragsted, Janne; Johansson, Emma; Lundberg, Kajsa; Mossegård, Jonatan; Byström, Joakim; Olsson, Olle

\section{Published in:}

Energy Conversion and Management

Link to article, DOI:

10.1016/j.enconman.2018.08.008

Publication date:

2018

Document Version

Peer reviewed version

Link back to DTU Orbit

Citation (APA):

Ahlgren, B., Tian, Z., Perers, B., Dragsted, J., Johansson, E., Lundberg, K., Mossegård, J., Byström, J., \& Olsson, O. (2018). A simplified model for linear correlation between annual yield and DNI for parabolic trough collectors. Energy Conversion and Management, 174, 295-308. https://doi.org/10.1016/j.enconman.2018.08.008

\section{General rights}

Copyright and moral rights for the publications made accessible in the public portal are retained by the authors and/or other copyright owners and it is a condition of accessing publications that users recognise and abide by the legal requirements associated with these rights.

- Users may download and print one copy of any publication from the public portal for the purpose of private study or research.

- You may not further distribute the material or use it for any profit-making activity or commercial gain

- You may freely distribute the URL identifying the publication in the public portal 


\section{A simplified model for linear correlation between annual yield and DNI for parabolic trough collectors \\ 4 Benjamin Ahlgren ${ }^{1}$, Zhiyong Tian ${ }^{2}$, Bengt Perers ${ }^{2}$, Janne Dragsted ${ }^{2}$, Emma Johansson ${ }^{1}$, Kajsa Lundberg ${ }^{1}$, Jonatan Mossegård ${ }^{3}$, Joakim Byström ${ }^{3}$, Olle Olsson ${ }^{3}$ ${ }^{1}$ Umeå University, SE-901 87 Umeå, Sweden \\ ${ }^{2}$ Department of Civil Engineering, Technical University of Denmark, Brovej Building 118, Lyngby, 2800, Denmark \\ ${ }^{3}$ Absolicon Solar Collector AB, Fiskaregatan 11, SE-871 33 Härnösand, Sweden}

\section{Abstract}

11 This paper proposes a simple method for estimating annual thermal performance of parabolic trough collectors (PTCs) based on a linear relation with annual DNI for a certain latitude. A case study with simulations for a novel concentrating solar collector in 316 locations for three operating temperature scenarios worldwide was carried out and showed promising results for the latitudes and continents investigated. For a certain latitude and mean operating temperature, the annual yield of a PTC was found to be linearly proportional to yearly DNI. The proposed method will serve as a simplified alternative to the steady-state and quasi-dynamic methods already used. Estimating performance based on yearly DNI can be used by design engineers to do quick preliminary planning of solar plants. Customers can also use this tool to evaluate existing solar collector installations. A TRNSYS/TRNSED tool that uses a steady-state model has been developed to carry out the simulations and it has been validated against a PTC array at Technical University of Denmark (DTU). The results show that the simplified method can give reliable estimates of long-term performance of parabolic trough collectors.

Keywords: Simplified methods, parabolic trough collectors, DNI, annual yield.

\section{Introduction}

The building sector consumes about $40 \%$ of the total society energy in the developed countries [1]. consumption in the building sector. Solar thermal energy systems are one of the most promising ways to reduce the fossil energy consumption. Large-scale solar collector arrays gain more and more interest in the district heating networks or industry processes. Small-size concentrating solar collectors with high efficiency is suitable for these applications.

Sweden was the first country to apply large solar collector arrays into district heating systems in the 1980s. Then solar district heating plants gained success in Denmark [2], Germany, and Austria. Denmark is presently the front runner worldwide in the solar district heating plants [3]. By the end of 2016, more than 1.3 million $\mathrm{m}^{2}$ of solar collectors were in operation in Denmark. China is an emerging market for large-scale solar thermal plants, reducing the air pollution in the winter. 
Most solar collectors in existing plants are ground-mounted flat plate collectors and previous research is mainly on flat plate collector arrays. Parabolic trough collectors have shown more and more advantages in the low temperature level $70-150{ }^{\circ} \mathrm{C}$ [4]. The heat loss of concentrating solar collectors is much lower than the flat plate collectors so higher temperature heat can be produced with good efficiency. This guarantee better performance in industry applications and charging of heat storages compared to flat plate collector arrays.

Traditionally, complicated procedures or expensive software is used to calculate the performance of the parabolic trough collector array. To make qualified assumptions on the thermal performance of a PTC array, it is important to simulate the performance in a quick and cost-effective way.

\subsection{Previous simulation work}

TRNSYS is used widely in solar thermal energy systems simulation [5]. Most users of TRNSYS are researchers, focusing on the research purpose [6]. Bava. et al. [7] developed a MATLAB-TRNSYS model on large solar collector fields for district heating networks. Kong. et al. [8], [9] proposed a new transfer function method for flat plate collectors. Deng. et al. [10]-[12] developed a secondorder transfer function model for dynamic test on the flat plate collectors. Tian. et al. [13]-[15] applied the quasi-dynamic model to simulate the short and long-term performance for both largescale flat plate collector fields and parabolic trough collector fields.

Vela Solaris [16] has developed a commercial simulation tool for designing engineers and energy consultancies that is called Polysun. The RISE Research Institutes of Sweden has developed a userfriendly standardized open source tool for calculating the annual energy output for solar collectors available in the market - ScenoCalc [17]. The tool is now being used within the Solar Keymark, the quality labeling of solar thermal products in Europe for calculating certified annual collector output. The tool was developed within the EU-project Quality Assurance in Solar Thermal Heating and Cooling Technologies (QAIST) and uses a Microsoft Excel interface. Even though ScenoCalc is further developed by Berberich. et al. [18], one drawback of ScenoCalc is that the shadow between the collector rows, in a field, is not taken into consideration.

Many existing publications on the parabolic trough collectors are on the detailed optical models and heat transfer models [19]-[20]. Reddy. et al. [21] did sensitivity studies of thermal performance characteristics based on optical parameters for direct steam generation from parabolic trough collectors. Xu. et al. [22] developed a numerical model to quantify several important factors affecting heat losses, and reveal the relationship between heat losses and the overall performance of parabolic trough solar collectors under various boundary conditions. Monte Carlo Ray Tracing method (MCRT) and Finite Volume Method have been widely used to determine optical performance or thermal performance of parabolic trough collectors [23]-[28]. ANSYS - Fluent was also widely used by the researchers to calculate the performance of parabolic trough collectors [29]-[32]. This research may be useful to develop single parabolic trough collector components for the manufactures. However, publications on accurate and quick estimation of the performance of large PTC arrays are limited, as far as we know. A simple model is necessary for the solar industry and end-users to guarantee the thermal performance of parabolic trough collectors.

\subsection{Scope}

Parabolic trough collectors mainly use the beam radiation to produce heat [33]. This study proposes a simple prediction model of annual performance of large parabolic trough array based on a linear 
relation to yearly DNI, at a certain latitude worldwide. That model makes it possible also for nonexperts to plan and evaluate collector fields since annual DNI data is easily accessible for most locations, e.g. through Global Solar Atlas [34]. It enables solar companies and engineers to speed up their preliminary planning of solar thermal plants. It also enables end-users around the world to better understand the potential of implementing solar energy.

This study aims to verify the hypothesis of linearity between annual output and total yearly DNI by running a big set of simulations, 316 locations under three operating temperature scenarios (948 cases). The simulations are done using a self-developed and validated TRNSYS/TRNSED simulation tool.

\section{Methods}

The methods of this study can be divided into two parts. The first one is to get simulated data based on the solar collector model. This includes both developing a TRNSYS/TRNSED tool for multiple simulations and validation against measured collector data. The second part is comparing the annual output with the yearly DNI to test the hypothesis of linearity.

\subsection{Solar collector model}

The solar collector modelling, testing and simulation methodologies can be divided into steady-state (SST), quasi-dynamic (QDT) and fully dynamic (DT) methods. The method of modelling and performance was carefully analyzed in [35] which is the fundamental basis for the simulation tool used in this paper. The basic collector model concept was analyzed and validated for a full operating season by Perers [36].

The simplified SST model for collector yield used in this study can be expressed as Equation (1)(3) [37].

$Q / A=F^{\prime}(\tau \alpha) K_{\theta b}\left(\theta_{L}, \theta_{T}\right) G_{b}+F^{I}(\tau \alpha) K_{\theta d} G_{d}-c_{1}\left(T_{m}-T_{a}\right)-c_{2}\left(T_{m}-T_{a}\right)^{2}$

where

$$
K_{\theta b}\left(\theta_{L}, \theta_{T}\right)=K_{\theta b}\left(\theta_{L}\right) K_{\theta b}\left(\theta_{T}\right)
$$

and

$$
K_{\theta b}\left(\theta_{L}\right)=1-b_{0}\left(\frac{1}{\cos \theta_{I_{e}}}-1\right)
$$

In this paper, the collector is tracking the sun with the tracking axis aligned north to south so that $\mathrm{K}\left(\theta_{\mathrm{T}}\right)=1.0$. When the $\theta_{\mathrm{L}}$ approaches $90^{\circ}$ the IAM $\left(\mathrm{K}_{\theta \mathrm{b}}\left(\theta_{\mathrm{L}}\right)\right)$ decreases, negative IAM values was set to 0 since the IAM reaches zero before $\theta_{\mathrm{L}}=90^{\circ}$.

The simplified SST model was used to get very fast annual simulations since many locations and three operating temperatures were to be investigated. The sky radiance and wind terms was assumed to be zero [37] since the PTC used here is covered with glass which makes those terms small. The capacitance term was neglected since one-hour resolution data was used and capacitance is insignificant on that time resolution [38]. The simplification without thermal capacitance term is also chosen in the ScenoCalc tool [17] used in the Solar Keymark. 
The principle of TRNSYS Type 30 [39] was used to simulate the shadows between the solar collector troughs in an array. The collector length was assumed to be infinite, hence only shadowing between rows were accounted for.

\subsubsection{Validation of solar collector model} collector model. T160 is a tracking concentrating collector with parabolic mirrors and a selective absorber tube placed in the focal line position. It is covered with glass that also is part of the mechanical structure. The design is optimized and adapted to fast robot manufacturing.

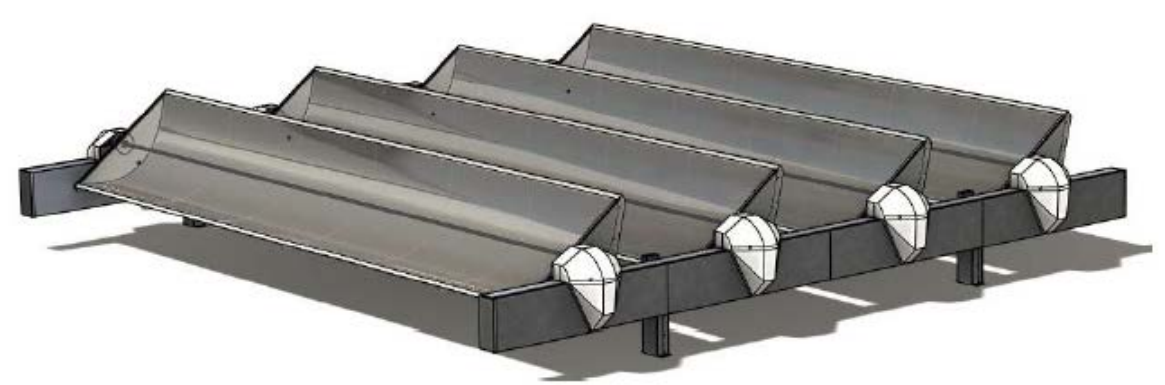

Figure 1. Concentrating solar collector Absolicon T160 [40].

In the basic installation design, the tracking axis is horizontal and can be installed in any azimuthal direction depending on local conditions like available roof or ground area direction. Load distribution over the day and year is also a factor.

The dimensions of T160 parabolic trough collector are listed in Table 1. The troughs are quite short so that the collector can have tracking axis tilt, which has been found to increase the annual performance significantly, especially at higher latitudes. 


\begin{tabular}{|c|c|}
\hline Length & $5.490 \mathrm{~m}$ \\
\hline Width & $1.056 \mathrm{~m}$ \\
\hline $\begin{array}{c}\text { Absorber } \\
\text { area }\end{array}$ & $\begin{array}{c}0.44 \mathrm{~m}^{2} \text { (specified by } \\
\text { Absolicon) }\end{array}$ \\
\hline Gross area & $5.8 \mathrm{~m}^{2}$ (measured by RISE) \\
\hline
\end{tabular}

141 The solar collector model used for the simulations in this paper was validated in a case study against measurements for an array of 4 troughs at DTU in Copenhagen. The measurements lasted for 2.5 months starting July 2017. The parameters of T160 collector has been tested (QDT) at RISE (Research Institutes of Sweden) during 2016 [41] and the test results from RISE was used in the collector model when validating against measured data at DTU, see Figure 2.

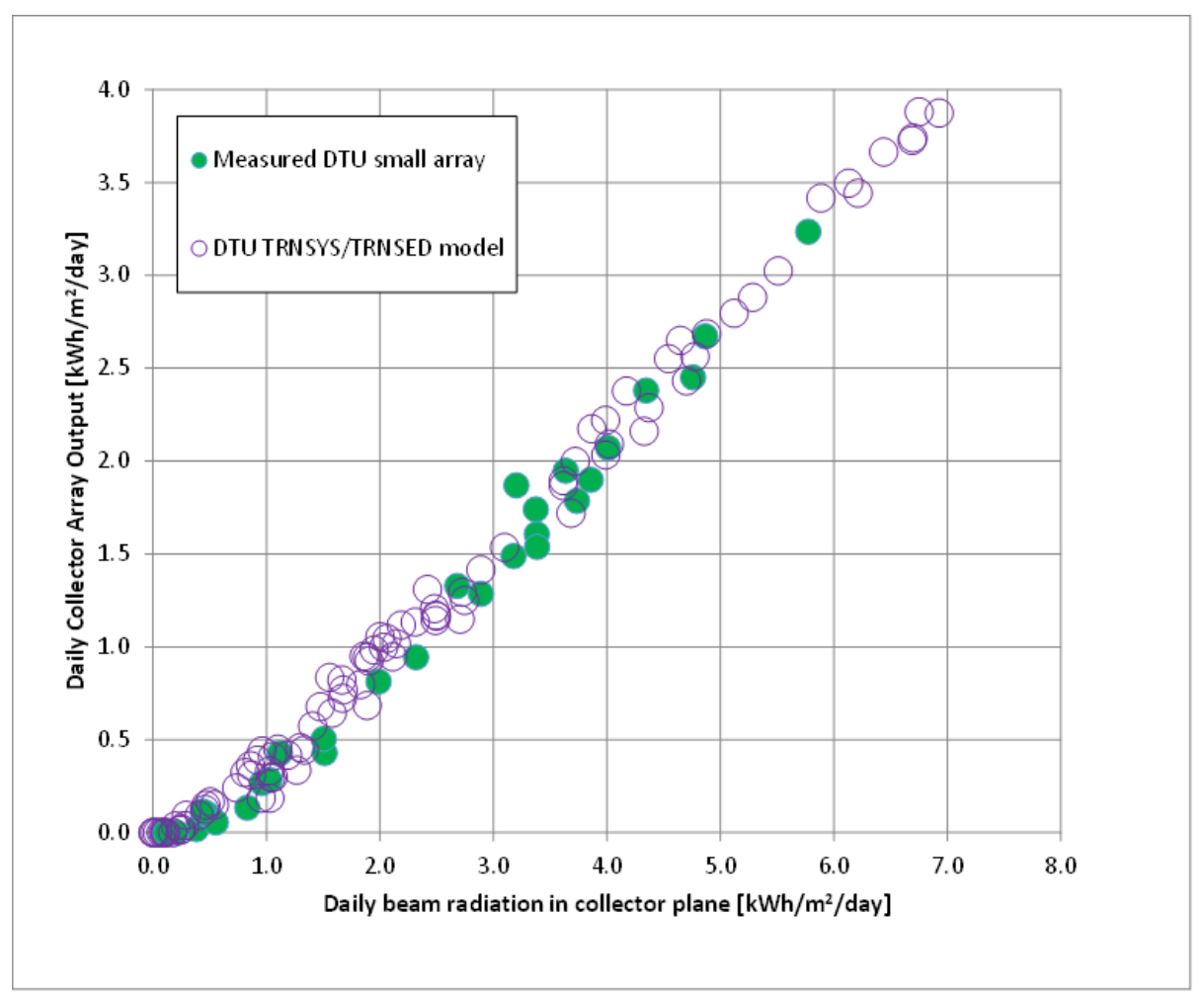

Figure 2. Validation of the simulation tool used versus measured data for a four troughs-array at DTU in Copenhagen Denmark. Measurements during July to mid-September 2017. Green dots represent measured performance and purple rings is simulated performance with the tool used in this study.

Figure 2 gives a solid indication that the simulations in this paper should be realistic and give accurate long-term performance results. The measured and simulated energy outputs have good agreements in both sunny and cloudy days. 


\subsection{Simplified model based on DNI}

The hypothesis was that the annual collector array performance would depend linearly on annual DNI, as expressed in Equation (4)

$$
Q=\mathrm{k}_{1} \times D N I
$$

where $Q$ is the annual yield, $\mathrm{k}_{1}$ is a constant and $D N I$ is the yearly DNI. A significant latitude effect was found for a horizontal north-south tracking axis so the formula was elaborated to Equation (5) as

$$
Q=k_{1} \text { (latitude) } \times D N I
$$

where $\mathrm{k}_{1}$ is dependent on the latitude. This is a very simple relation that can be used quickly if just the local DNI and latitude is known.

There is also an operating temperature dependence in $\mathrm{k}_{1}$. The full basic formula should then be Equation (6)

$$
\left.Q=k_{1} \text { (latitude, } T_{m}\right) \times D N I
$$

where $\mathrm{k}_{1}$ is dependent on both latitude and mean operating temperature, $T_{m}$.

\subsubsection{Verification of simplified model}

To confirm the hypothesis described above (Equations 4-6), a set of 862 climate conditions was generated as typical meteorological years (TMY) from weather stations (non-interpolated data) in TRNSYS 17 [42]. The time resolution of the climate files was one hour. Climates closer than $\pm 2^{\circ}$ to latitudes $-50^{\circ},-40^{\circ}, \ldots, 60^{\circ}, 70^{\circ}$ was selected to define $\mathrm{k}_{1}$ for all 13 latitudes worldwide. Due to lack of weather stations at some latitudes the number of climates selected for each latitude varied between 1 (at latitude $-50^{\circ}$ ) and 100 (at latitude $40^{\circ}$ ), see Table 3-5. The climate at $-50^{\circ}$ was kept even though it was the only one for the latitude. It was done to see whether it followed the pattern of decreasing $\mathrm{k}_{1}$ at higher or lower latitudes.

Total 316 climate stations were selected and investigated to confirm the hypothesis of the simplified model. The selected climate locations are indicated with red crosses in Figure 3. 


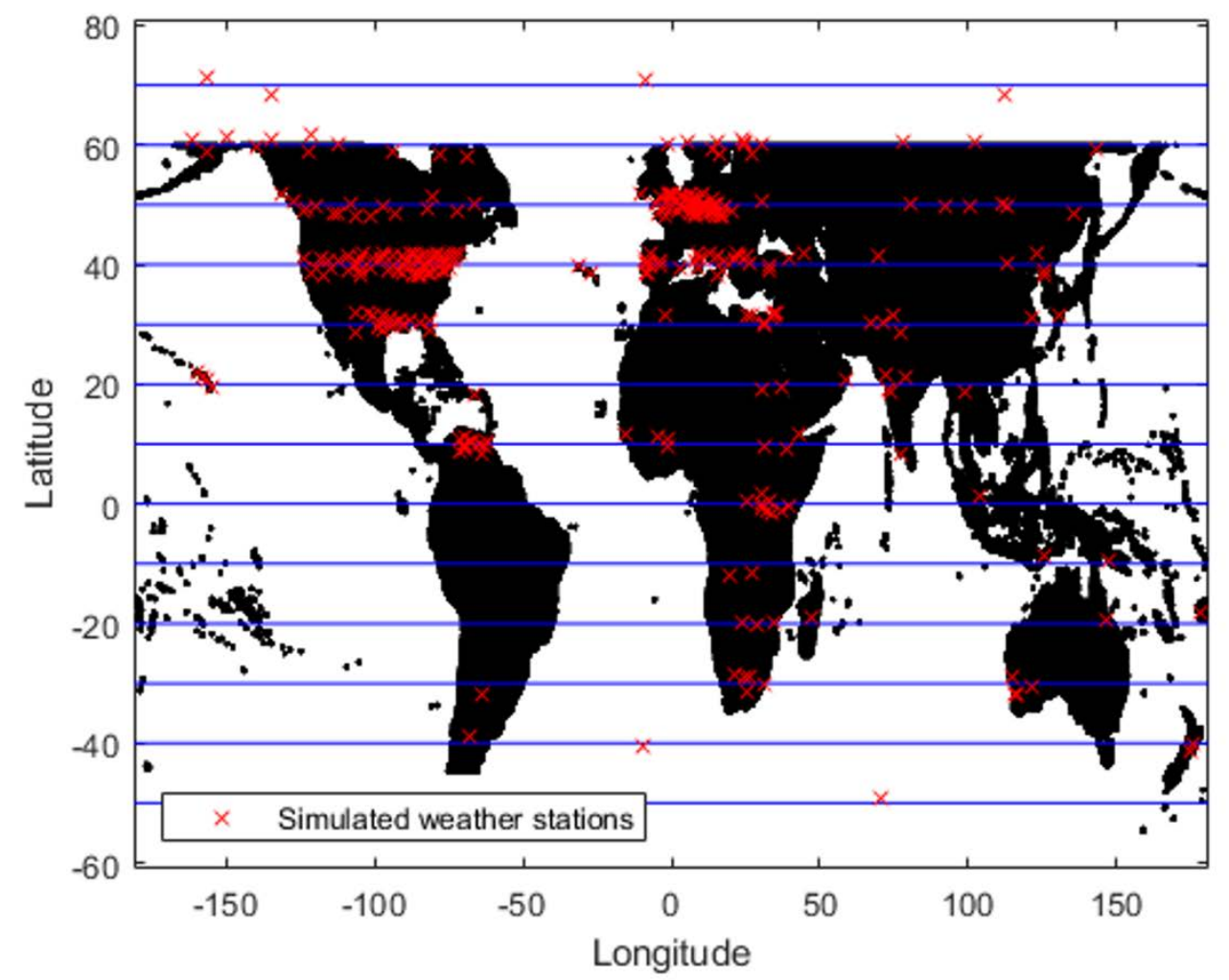

Figure 3. The locations where the performance was simulated is shown with red crosses. More locations were chosen on some latitudes due to easier access to accurate weather data. Locations where interpolated annual DNI can be obtained from e.g. Global Solar Atlas [34] are indicated in black. The investigated latitudes are marked with blue lines.

Simulations were done with the TRNSYS/TRNSED tool for a T160 array of 20 collectors for three mean operating temperatures $\left(T_{m}\right), 85^{\circ} \mathrm{C}, 120^{\circ} \mathrm{C}$ and $160^{\circ} \mathrm{C}$. The TRNSYS/TRNSED tool was validated in Section 2.1.1. The collectors were tracking the sun movement from east to west with a horizontal north to south tracking axis. The center to center row distance of the troughs was $1.4 \mathrm{~m}$ and their azimuth angle (deviation from south) was $0^{\circ}$. The collector parameters used is from preliminary test results at SPF [43] for the latest T160 model and can be seen in Table 2.

Table 2. Collector parameters from preliminary SPF test results for Absolicon [25]. The parameters are based on aperture area.

\begin{tabular}{l|ll} 
Parameter & Value & Unit \\
\hline $\boldsymbol{F}^{\prime}(\boldsymbol{\tau} \boldsymbol{\alpha})$ & 0.7661 & {$[-]$} \\
$\mathbf{b}_{\mathbf{0}}$ & 0.210 & {$[-]$} \\
$\boldsymbol{K}_{\boldsymbol{\theta} \boldsymbol{d}}$ & 0.08586 & {$[-]$} \\
$\mathbf{c}_{1}$ & 0.3677 & {$\left[\mathrm{~W} / \mathrm{m}^{2} \mathrm{~K}\right]$} \\
$\mathbf{c}_{2}$ & 0.003224 & {$\left[\mathrm{~W} / \mathrm{m}^{2} \mathrm{~K}^{2}\right]$} \\
Aperture width & 1.056 & {$[\mathrm{~m}]$}
\end{tabular}

The simulated yield for each weather station and operating temperature was grouped by latitude and compared to DNI. Linear regression then gave $k_{1}$ in Equation 6. 


\subsection{Offset at zero DNI}

When the simplified model was developed there was a discussion about whether to include an offset term, related to the heat losses from the collector array. The normal Input-Output curves have such an offset [44] if daily values was plotted. The motivation to make the analysis without offset is that the collector heat losses are very small for a concentrating collector and the annual operating time will also vary systematically with available annual solar radiation, DNI in this case [35]. Therefore, in a tentative zero DNI case, the operating time and thereby the heat losses would also be close to zero and the offset will not be a relevant parameter in the model.

Previous studies of this kind of very simple annual performance relations, for flat plate and vacuum tube collector's performance [45], indicated a negative zero offset when applying a similar collector model. They plotted annual collector output versus global horizontal radiation instead of DNI. In that case the variation in global radiation was due to small changes between different real years and not different locations. The heat losses of the concentrating collectors studied in this paper are in the range of 5-10 times lower (around $0.5-1.0 \mathrm{~W} /\left(\mathrm{m}^{2} \cdot \mathrm{K}\right)$ for a medium concentrating collector, compared to $3-4 \mathrm{~W} /\left(\mathrm{m}^{2} \cdot \mathrm{K}\right)$ for a typical flat plate collector) than for flat plate collectors so the offset should be very small. Collector test parameters including heat losses for various collector types, can be found in the Solar Keymark Database [46].

A full verification of the zero-offset assumption cannot be done by statistical methods as there are no locations with climates that has even close to zero annual DNI on earth. Therefore, it was decided to make a model design freeze for the simplified tool at this level and constrain the model to pass the origin.

\section{Results and discussions}

Plots of the results for mean operating temperature 85 and $120^{\circ} \mathrm{C}$, divided by latitude, is displayed in Figure 4-9 in this section. Plots for $T_{m}=160^{\circ} \mathrm{C}$ can be seen in Appendix. All the results indicate a strong linearity around all investigated latitudes except at $-50^{\circ}$ where no conclusions can be drawn due to lack of data. The biggest difference between the mean operating temperatures is the lower $k_{1}$ and the slight increase in model error at higher temperature. Both are most likely due to the increased heat loss. $T_{m}=85^{\circ} \mathrm{C}$ and $T_{m}=120^{\circ} \mathrm{C}$ will here be discussed more in detail.

\subsection{Strong linearity}

\subsubsection{Mean operating temperature $85{ }^{\circ} \mathrm{C}$}

At $40^{\circ}$ north (Figure $4 \mathrm{~d}$ ) there were 100 weather stations available. The simplified model predicts an annual yield of $43.7 \%$ of available DNI there. As shown in the Figure $4 \mathrm{~d}$ the root-mean-square error (RMS) of the prediction was $\pm 26.2 \mathrm{kWh} /\left(\mathrm{m}^{2} \cdot \mathrm{y}\right)$. Most locations at the latitude were in the span of DNI 1100 to $1600 \mathrm{kWh} /\left(\mathrm{m}^{2} \cdot \mathrm{y}\right)$ and in that range the error was even smaller.

The widest span of DNI was found around $30^{\circ}$ north and that is also where the RMS error was biggest, $\pm 30 \mathrm{kWh} /\left(\mathrm{m}^{2} \cdot \mathrm{y}\right)$. Figure $4 \mathrm{e}$ indicates that the linearity holds over the whole span. Since the annual yield ranges from about 200 to $1300 \mathrm{kWh} /\left(\mathrm{m}^{2} \cdot \mathrm{y}\right)$, an RMS error of $\pm 30 \mathrm{kWh} /\left(\mathrm{m}^{2} \cdot \mathrm{y}\right)$ represents a relative error of 2.3 to $15 \%$ depending on whether the DNI was low or high on the location. 

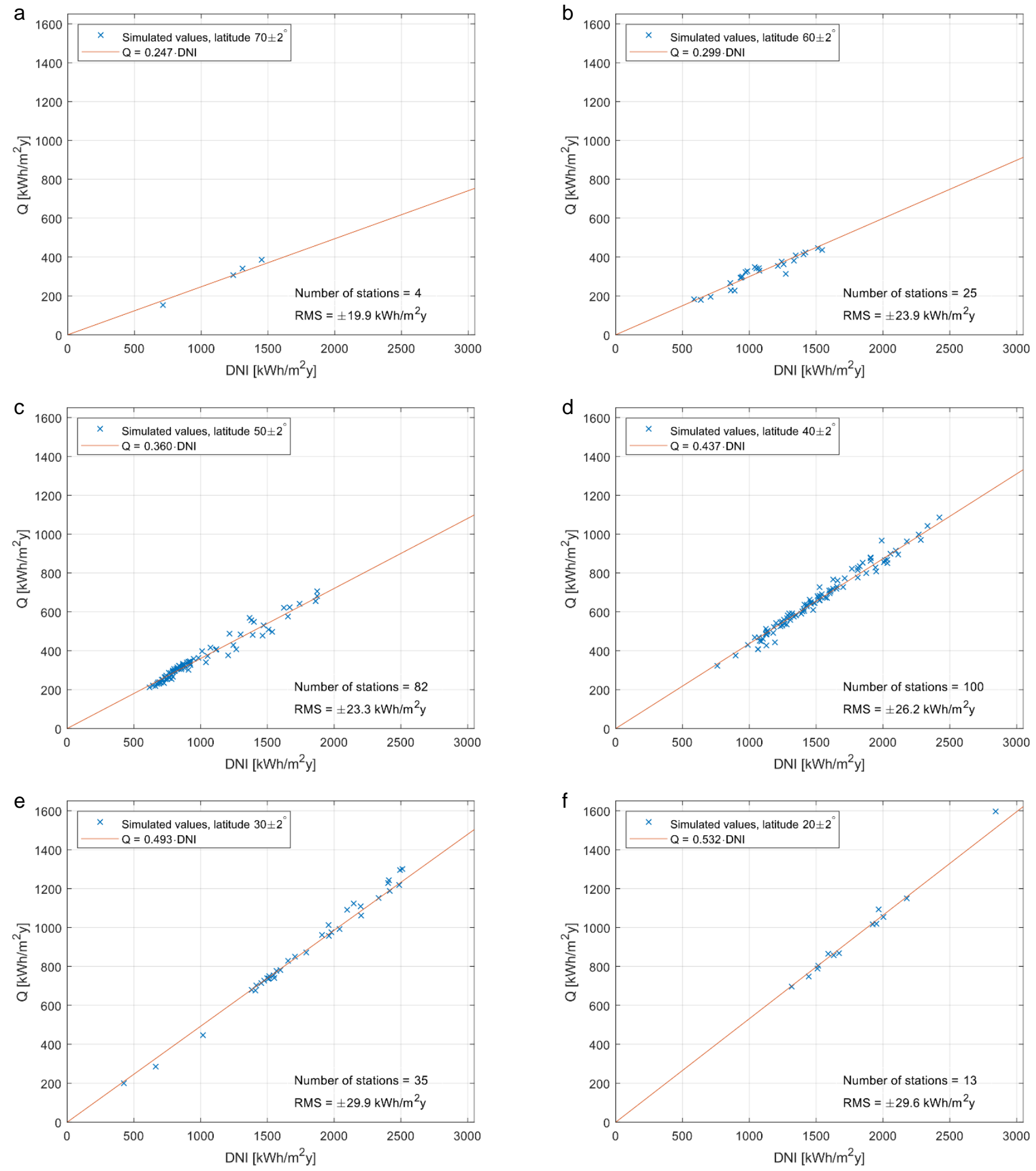

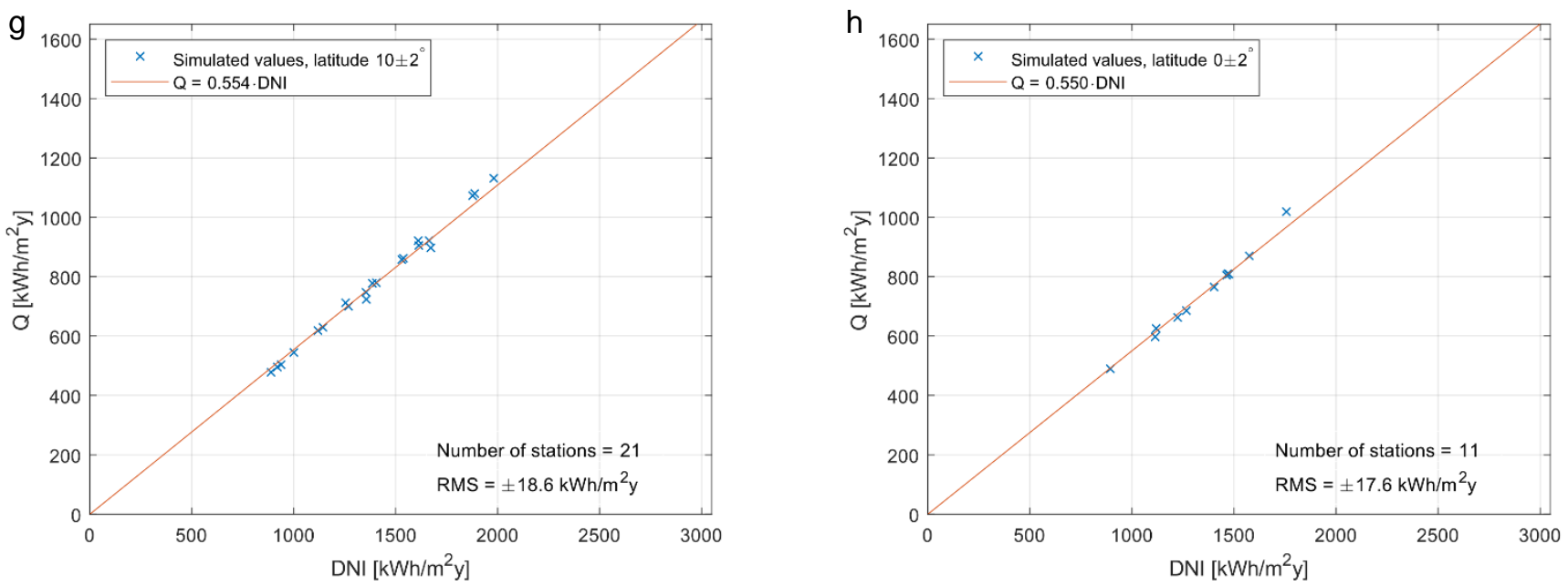

Figure 4a-h. Simulated values for annual T160 collector yield compared to DNI around latitudes $70^{\circ}, 60^{\circ}, \ldots$, $0^{\circ}$. Collector yield simulations based on a mean operating temperature of $85^{\circ} \mathrm{C}$. A linear regression is shown with a red line.

The longer from the equator, the lower the DNI, $k_{1}$ and hence the yield. At $50^{\circ}$ north most of the 82 weather stations received DNI in the range of 500 to $1000 \mathrm{kWh} /\left(\mathrm{m}^{2} \cdot \mathrm{y}\right)$ and $k_{1}$ was found to be 0.360 . The simulated yield was between 200 and $400 \mathrm{kWh} /\left(\mathrm{m}^{2} \cdot \mathrm{y}\right)$. An RMS of $\pm 23.3 \mathrm{kWh} /\left(\mathrm{m}^{2} \cdot \mathrm{y}\right)$ then represent 5.8 to $11.7 \%$ relative error. As one can see in Figure 4c, the variation around the regression line was bigger at higher DNI so the relative error was smaller where most of the 82 stations are.

There are fewer weather stations at the south of the equator, as shown in Figure 5a-e. The simulations based on the data available indicates strong linearity.
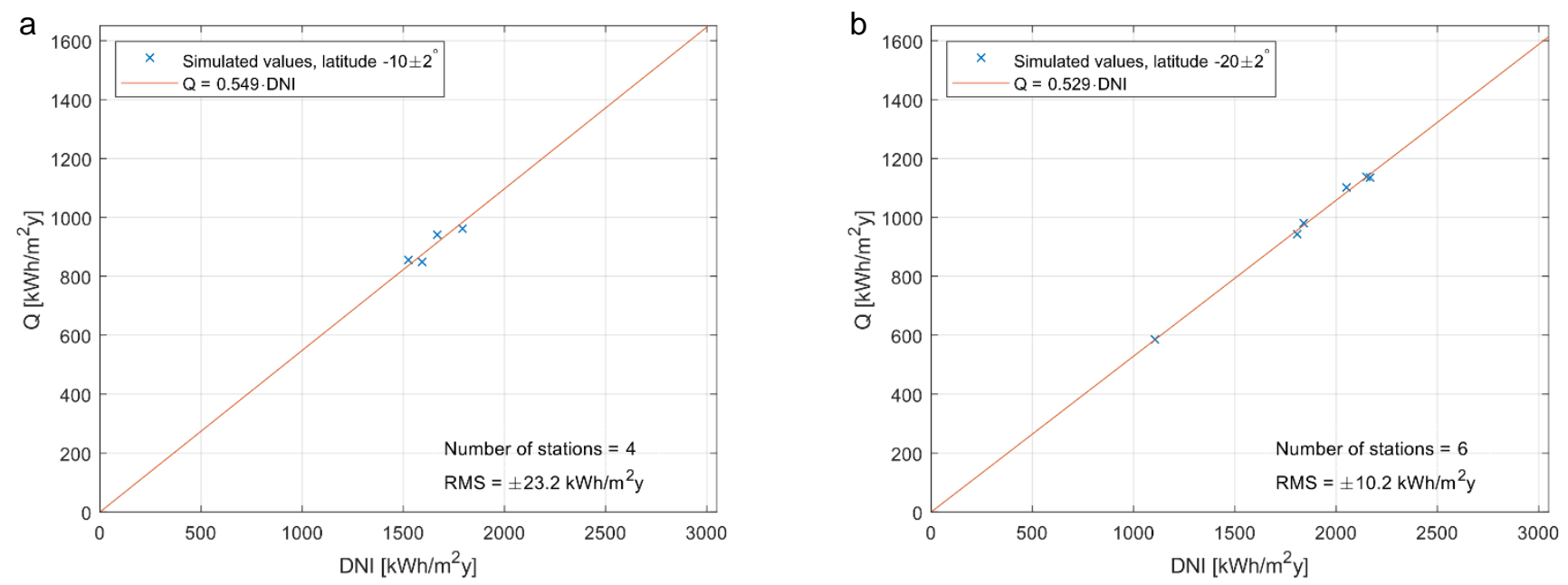

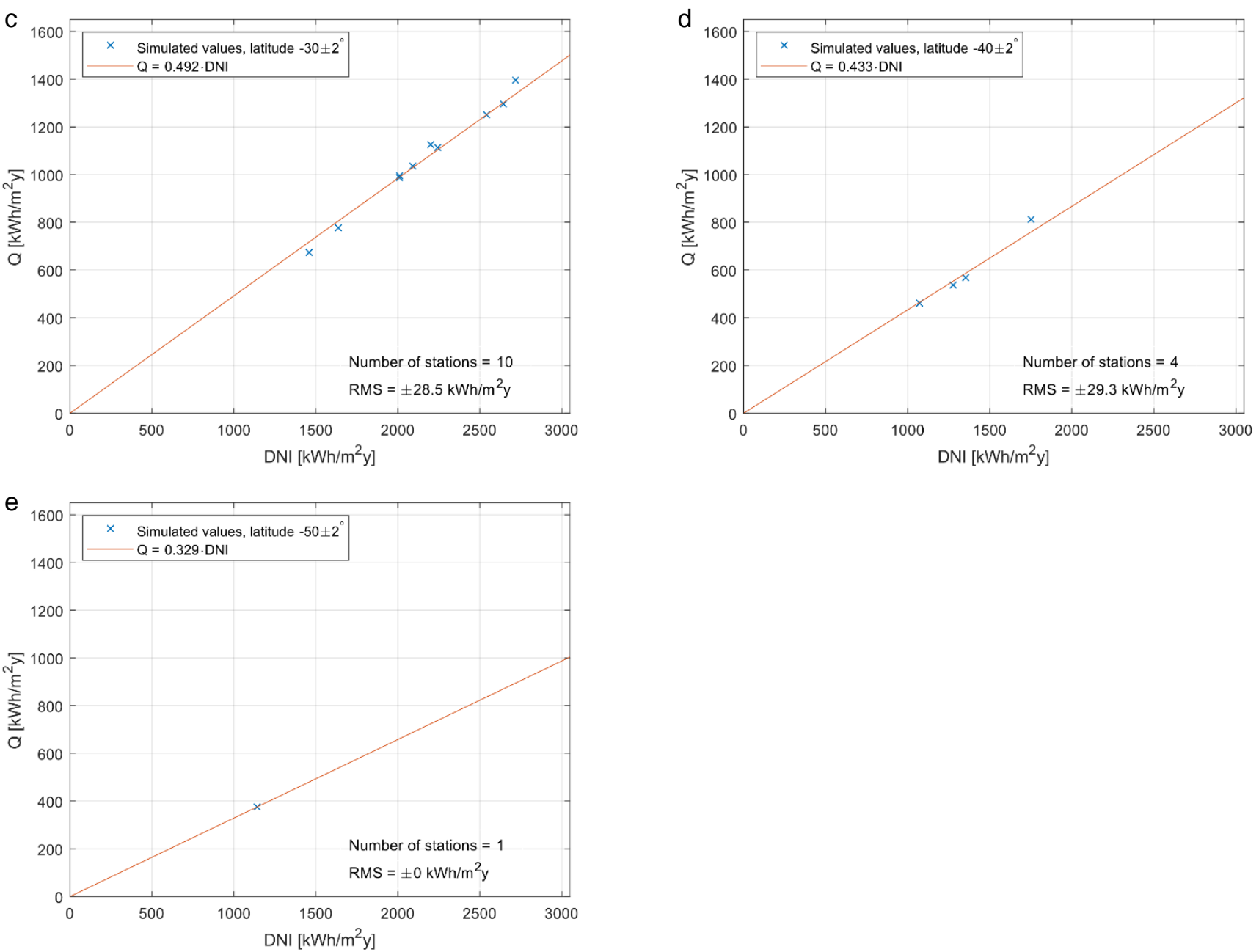

Figure 5a-e. Simulated values for annual T160 collector yield compared to DNI around latitudes $-10^{\circ}$, $-20^{\circ}, \ldots,-50^{\circ}$. Collector yield simulations based on a mean operating temperature of $85^{\circ} \mathrm{C}$. A linear regression is shown with a red line.

255 Figure 6 shows the slope $\left(k_{1}\right)$ of the regression lines for latitudes $-50^{\circ}$ to $70^{\circ}$ and the very 256 systematic variation with latitude. The slope is steepest at the equator and goes down towards the polar regions like a cosine curve. The relation is also quite symmetrical between north and south of the equator. 


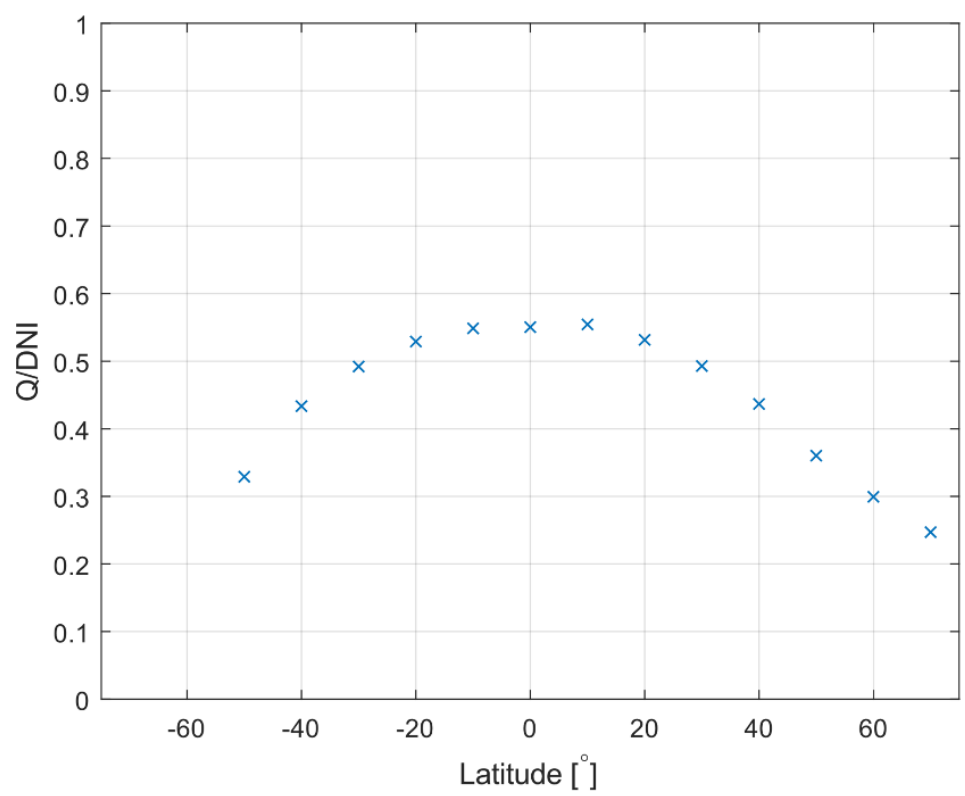

Figure 6. Energy output per DNI plotted against latitude. Collector yield simulations based on a mean operating temperature of $85^{\circ} \mathrm{C}$.

3.1.2 Mean operating temperature $120^{\circ} \mathrm{C}$.

The linearity between annual energy output and total yearly DNI is clear at this temperature scenario as well, see Figure 7 and 8 . The deviation from the linear regression is slightly bigger compared to the results in Section 3.1.1. The biggest RMS error is $\pm 40.5 \mathrm{kWh} /\left(\mathrm{m}^{2} \cdot \mathrm{y}\right)$ and is here found at latitude $20^{\circ}$ north.

The model is underestimating the yield at higher DNI at this mean operating temperature and is even more clear in the results for $T_{m}=160^{\circ} \mathrm{C}$ in Appendix if the results for latitude $40^{\circ}$ north in Figure 4d, Figure $7 d$ and Figure 10d are compared.
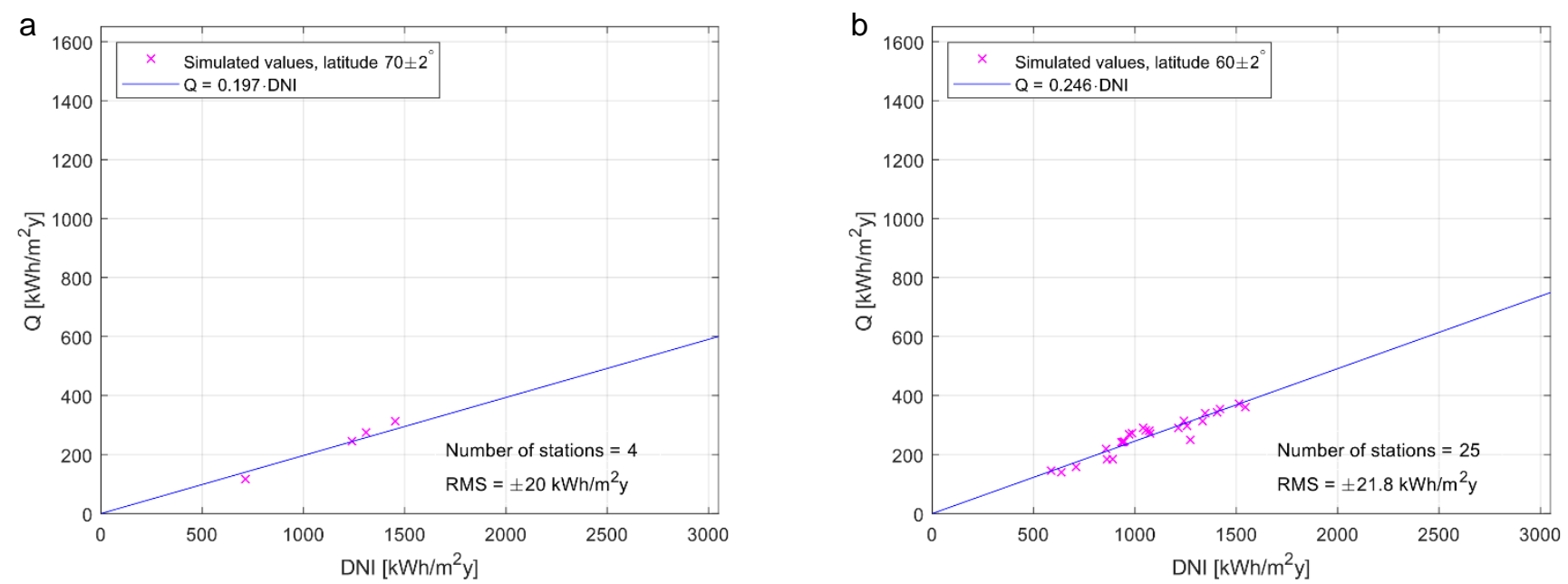

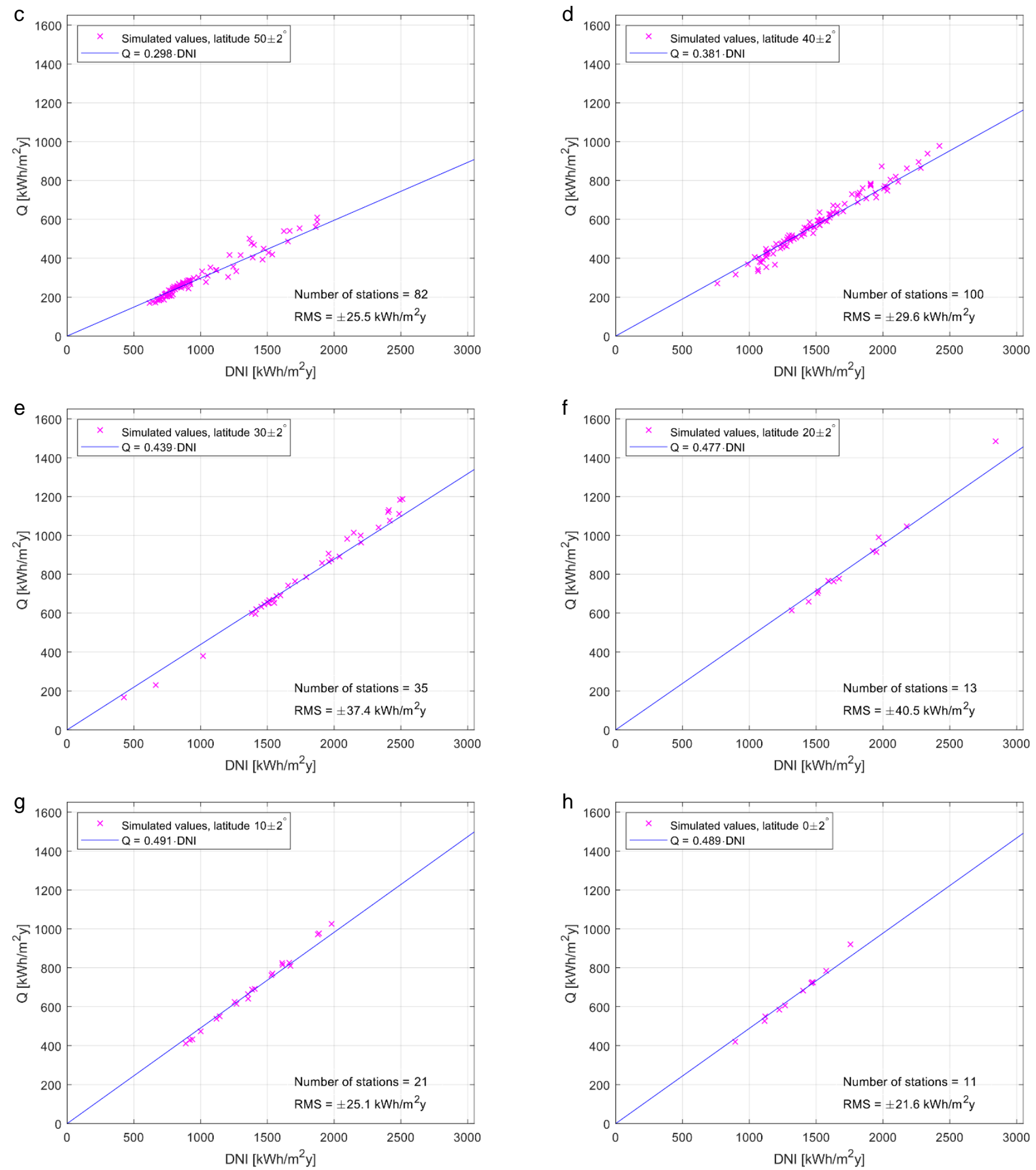

Figure 7a-h. Simulated values for annual T160 collector yield compared to DNI around latitudes $70^{\circ}, 60^{\circ}, \ldots$, $0^{\circ}$. Collector yield simulations based on a mean operating temperature of $120^{\circ} \mathrm{C}$. A linear regression is shown with a blue line. 

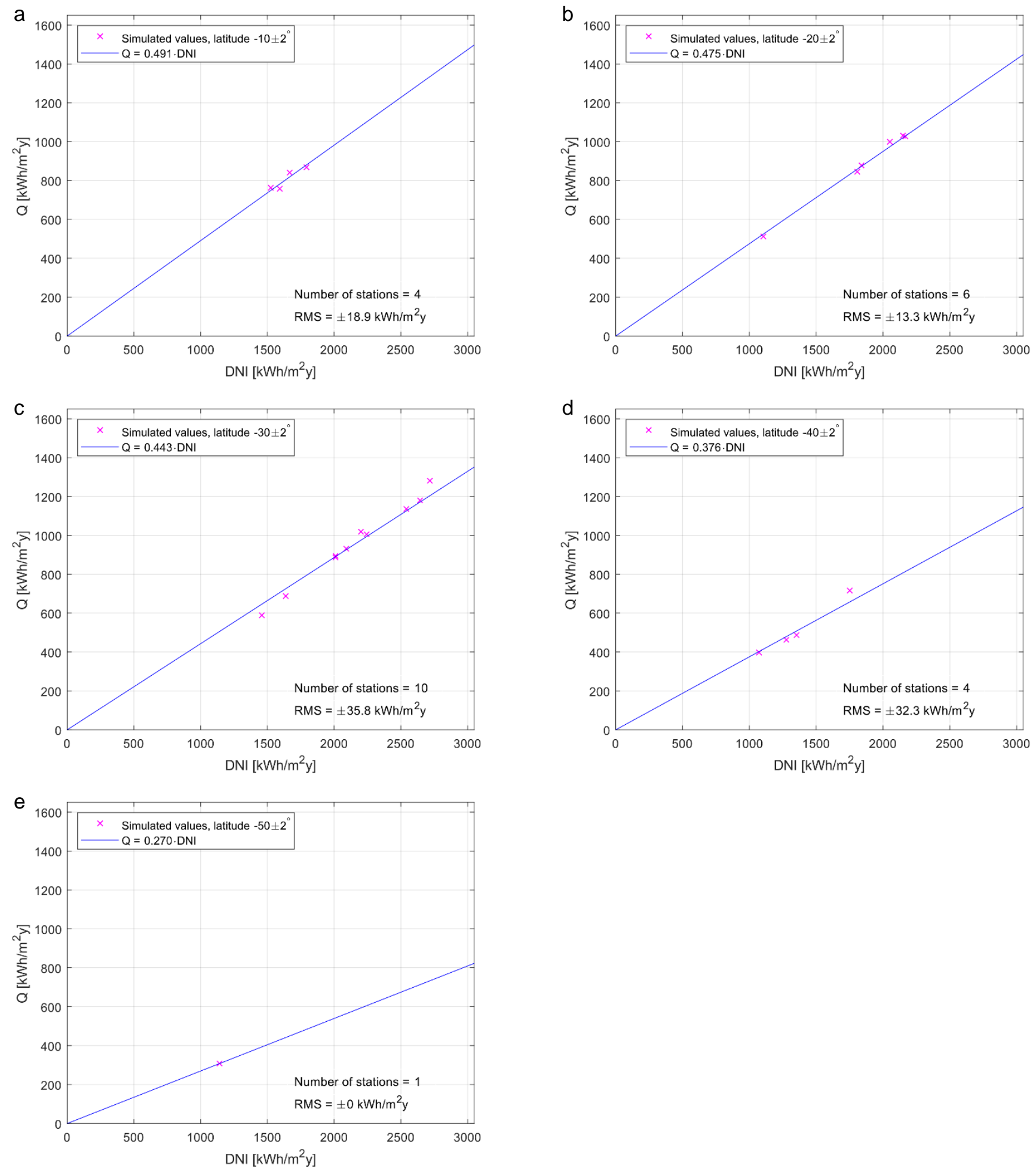

Figure 8a-e. Simulated values for annual T160 collector yield compared to DNI around latitudes $-10^{\circ}$, $-20^{\circ}, \ldots,-50^{\circ}$. Collector yield simulations based on a mean operating temperature of $120^{\circ} \mathrm{C}$. A linear regression is shown with a blue line. 
Figure 9 summarize the slopes in the plots above and the same decrease when moving away from the equator can be seen here as in Figure 6. The trends are similar, but the size differs a bit due to decreased efficiency at the higher temperature.

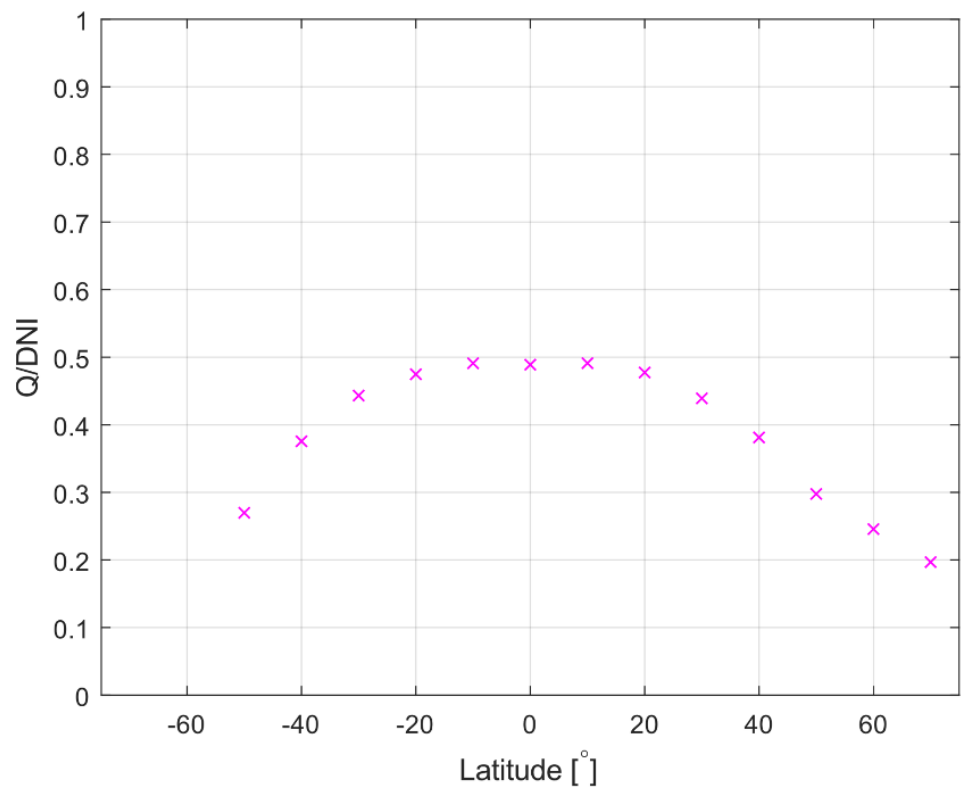

Figure 9. Energy output per DNI plotted against latitude. Collector yield simulations based on a mean operating temperature of $120^{\circ} \mathrm{C}$.

\subsection{Error analysis}

The models displayed in Figure 4-5 and Figure 7-8 is summarized in Table 3 and Table 4 respectively. The t-ratios indicate that the relation between annual yield and DNI is well described by the linear model for all the investigated $T_{m}$ and latitudes, except for $-50^{\circ}$ where no conclusions can be drawn due to lack of data. The slopes of the regression lines are steepest close to the equator as one would expect as the tracking axis is horizontal. The mean residuals of the regressions for $T_{m}=85^{\circ} \mathrm{C}$ were below $7 \%$ for all latitudes. 
Table 3. Results and error analysis of the linear models describing annual yield based on annual DNI for a certain latitude and a mean operating temperature, $T_{m}=85^{\circ} \mathrm{C}$. Note that for latitude $-50^{\circ}$ only one climate was simulated.

\begin{tabular}{lllllll} 
Figure & $\begin{array}{l}\text { Latitude } \\
\mathbf{( \mathbf { 2 }}^{\circ} \mathbf{)}\end{array}$ & $\boldsymbol{k}_{\mathbf{1}}$ & $\begin{array}{l}\text { Number of } \\
\text { weather stations }\end{array}$ & $\begin{array}{l}\mathbf{R M S} \text { error } \\
{\left[\mathbf{k W h} / \mathbf{m}^{\mathbf{2}} \cdot \mathbf{y}\right) \mathbf{]}}\end{array}$ & $\begin{array}{l}\text { Mean residual } \\
{[\mathbf{\%}]}\end{array}$ & t-ratio \\
\hline 4a & 70 & 0.247 & 4 & 19.9 & 6.92 & 35 \\
4b & 60 & 0.299 & 25 & 23.9 & 6.34 & 70 \\
4c & 50 & 0.360 & 82 & 23.3 & 4.81 & 149 \\
4d & 40 & 0.437 & 100 & 26.2 & 3.02 & 261 \\
4e & 30 & 0.493 & 35 & 29.9 & 2.61 & 197 \\
4f & 20 & 0.532 & 13 & 29.6 & 1.89 & 124 \\
4g & 10 & 0.554 & 21 & 18.6 & 1.87 & 206 \\
4h & 0 & 0.550 & 11 & 17.6 & 1.36 & 144 \\
5a & -10 & 0.549 & 4 & 23.2 & 2.56 & 78 \\
5b & -20 & 0.529 & 6 & 19.2 & 0.80 & 240 \\
5c & -30 & 0.492 & 10 & 28.5 & 2.08 & 125 \\
5d & -40 & 0.434 & 4 & 29.3 & 3.42 & 43 \\
5e & -50 & 0.329 & 1 & 0.00 & 0.00 & $\infty$
\end{tabular}

Comparing Table 3 and Table 4 gives a signal on how the efficiency from $D N I$ to $Q\left(k_{1}\right)$ decreases with increasing $T_{m}$. It also indicates the increasing difficulty of modelling collector yield at higher mean operating temperatures. Even so, the mean residual for $\mathrm{T}_{\mathrm{m}}=120^{\circ} \mathrm{C}$ is still below $9 \%$ and for $\mathrm{T}_{\mathrm{m}}=160^{\circ} \mathrm{C}$ it is below $12.5 \%$ (see Appendix).

Table 4. Results and error analysis of the linear models describing annual yield based on annual DNI for a certain latitude and a mean operating temperature, $T_{m}=120^{\circ} \mathrm{C}$. Note that for latitude $-50^{\circ}$ only one climate

313 was simulated.

\begin{tabular}{|c|c|c|c|c|c|c|}
\hline Figure & $\begin{array}{l}\text { Latitude } \\
\left( \pm 2^{\circ}\right)\end{array}$ & $k_{1}$ & $\begin{array}{l}\text { Number of } \\
\text { weather stations }\end{array}$ & $\begin{array}{l}\text { RMS error } \\
{\left[\mathbf{k W h} /\left(\mathbf{m}^{2} \cdot \mathbf{y}\right)\right]}\end{array}$ & $\begin{array}{l}\text { Mean residual } \\
\text { [\%] }\end{array}$ & t-ratio \\
\hline $7 a$ & 70 & 0.197 & 4 & 20.0 & 8.95 & 28 \\
\hline $7 b$ & 60 & 0.246 & 25 & 21.8 & 7.08 & 63 \\
\hline 7c & 50 & 0.298 & 82 & 25.5 & 6.14 & 117 \\
\hline $7 d$ & 40 & 0.381 & 100 & 29.6 & 3.87 & 207 \\
\hline $7 e$ & 30 & 0.439 & 35 & 37.4 & 3.88 & 149 \\
\hline $7 f$ & 20 & 0.477 & 13 & 40.5 & 2.53 & 84 \\
\hline $7 g$ & 10 & 0.491 & 21 & 25.1 & 2.93 & 141 \\
\hline $7 \mathrm{~h}$ & 0 & 0.489 & 11 & 21.6 & 2.17 & 107 \\
\hline $8 a$ & -10 & 0.491 & 4 & 18.9 & 2.27 & 85 \\
\hline $8 b$ & -20 & 0.475 & 6 & 13.3 & 1.35 & 171 \\
\hline $8 c$ & -30 & 0.443 & 10 & 35.8 & 2.95 & 91 \\
\hline $8 d$ & -40 & 0.376 & 4 & 32.3 & 4.34 & 34 \\
\hline $8 \mathrm{e}$ & -50 & 0.270 & 1 & 0.00 & 0.00 & $\infty$ \\
\hline
\end{tabular}


315 The simulation tool used in this study has been validated against long-term measurements on a small T160 collector array installed and carefully monitored at DTU in Denmark. DNI measurements were available at the test installation at DTU and the whole chain of calculations was validated. The thermal performances of the studied parabolic trough collector array with 316 climate station conditions in 13 latitudes worldwide for three temperature scenarios were simulated based on the validated tool. These conclusions may be drawn:

(1) The hypothesis of a linear relation between annual PTC yield and DNI for a certain latitude was confirmed on 12 of the 13 investigated latitudes under three temperature scenarios. For the $13^{\text {th }}$ latitude, $50^{\circ}$ south, only one weather station was found so no conclusions can be drawn there. The general conclusion is that the annual performance of a tracking concentrating collector of type Absolicon T160 can be predicted quite accurately based on the proposed simplified model. Within $7 \%$ for $\mathrm{T}_{\mathrm{m}}=85^{\circ} \mathrm{C} 9 \%$ for $\mathrm{T}_{\mathrm{m}}=120^{\circ} \mathrm{C}$ and $12.5 \%$ for $\mathrm{T}_{\mathrm{m}}=160^{\circ} \mathrm{C}$, based on only latitude and total yearly DNI. Simulation values like the ones listed in Table 3 could easily be used to determine collector performance and to do quick estimates. There is a possibility to save both time and money by continuing developing simple prediction models that can be used in various manners where an accuracy of $12.5 \%$ is enough. All kinds of modelling based on normal years involve uncertainties, both traditional solar collector model simulations and this simple prediction model. The real year DNI is for example expected to deviate in the range of \pm 8 to $\pm 15 \%$ according to [34].

(2) Based on the plots for $T_{m}=160^{\circ} \mathrm{C}$ in Appendix one can argue whether it was a good decision to constrain the model to pass the origin. There is a trend that signals an offset in the plots. Higher mean operating temperatures increases the heat losses and hence undermine the arguments for keeping the constraint. In future work one should again consider whether an offset is needed, especially if even higher temperatures are modelled. It seems that at higher $\mathrm{T}_{\mathrm{m}}$, the model now tends to underestimate at high DNI and overestimate at low DNI.

At present, only the case of horizontal north south axis direction has been investigated. But the relatively small collector array module design, is also suitable for application with tilt of the tracking axis and change of the azimuth according to local weather and installation conditions. This can be investigated by simulations in the future and preliminary simulations indicates a large performance improvement potential. It will therefore be of future interest to construct similar models that can handle tilts and rotations of collector fields.

The cosine behavior of $k_{1}$, see Figure 6,9 and 12, will also be analyzed more in future work. The spans around latitudes are likely to cause a minor scatter in the model. This could be minimized by analyzing the cosine behavior in detail. 


\begin{tabular}{|c|c|c|}
\hline Variables & Description & Unit \\
\hline $\mathbf{Q} / \mathbf{A}$ & Collector yield per area. & {$\left[\mathrm{W} / \mathrm{m}^{2}\right]$} \\
\hline $\mathbf{G}_{\mathbf{b}}$ & $\begin{array}{l}\text { Beam solar radiation in the } \\
\text { collector plane. }\end{array}$ & {$\left[\mathrm{W} / \mathrm{m}^{2}\right]$} \\
\hline $\mathbf{G}_{\mathbf{d}}$ & $\begin{array}{l}\text { Diffuse solar radiation in } \\
\text { collector plane. }\end{array}$ & {$\left[\mathrm{W} / \mathrm{m}^{2}\right]$} \\
\hline $\mathbf{T}_{\mathrm{m}}$ & $\begin{array}{l}\text { Mean fluid temperature } \\
\left(T_{\text {in }}+T_{\text {out }}\right) / 2 \text {. }\end{array}$ & {$\left[{ }^{\circ} \mathrm{C}\right]$} \\
\hline $\mathbf{T}_{\mathrm{a}}$ & $\begin{array}{l}\text { Ambient temperature close to } \\
\text { collector (in the shade) }\end{array}$ & {$\left[{ }^{\circ} \mathrm{C}\right]$} \\
\hline $\boldsymbol{\theta}_{\mathrm{L}}, \boldsymbol{\theta}_{\mathrm{T}}$ & $\begin{array}{l}\text { Biaxial incidence angles for } \\
\text { beam radiation onto the } \\
\text { collector plane in longitudinal } \\
(\mathrm{L}) \text { and transversal }(\mathrm{T}) \\
\text { direction from the normal. }\end{array}$ & {$\left[{ }^{\circ}\right]$} \\
\hline Parameters & Description & Unit \\
\hline $\mathbf{F}^{\prime}(\tau \boldsymbol{\alpha})$ & $\begin{array}{l}\text { Zero loss efficiency of the } \\
\text { collector for beam radiation, at } \\
\text { normal incidence angle }\end{array}$ & {$[-]$} \\
\hline $\mathbf{K}_{\boldsymbol{\theta} \mathbf{b}}\left(\boldsymbol{\theta}_{\mathrm{L}}, \boldsymbol{\theta}_{\mathrm{T}}\right)$ & $\begin{array}{l}\text { Incidence angle modifier } \\
\text { (IAM) for beam solar } \\
\text { radiation. Can be generalized } \\
\text { to } K_{\theta b}\left(\theta_{L}\right) \text { in the case of a } \\
\text { tracking concentrating } \\
\text { collector with north to south } \\
\text { tracking axis. }\end{array}$ & {$[-]$} \\
\hline $\mathbf{b}_{0}$ & $\begin{array}{l}\text { Incidence angle modifier } \\
\text { coefficient. }\end{array}$ & {$[-]$} \\
\hline $\mathbf{K}_{\theta \mathrm{d}}$ & $\begin{array}{l}\text { Incidence angle modifier for } \\
\text { diffuse solar radiation. }\end{array}$ & {$[-]$} \\
\hline $\mathbf{c}_{1}$ & Heat loss coefficient & {$\left[\mathrm{W} / \mathrm{m}^{2} \mathrm{~K}\right]$} \\
\hline $\mathbf{c}_{2}$ & $\begin{array}{l}\text { Temperature dependence in } \\
\text { heat loss coefficient }\end{array}$ & {$\left[\mathrm{W} / \mathrm{m}^{2} \mathrm{~K}^{2}\right]$} \\
\hline
\end{tabular}


Absolicon Solar Collector AB.

\section{References}

359

360

361

362

363

364

365

366

367

368

369

370

371

372

373

374

375

376

377

378

379

380

381

382

383

384

385

386

387

388

389

390

391

392

393

394

395

396

397

398

399

[1] Z. Tian et al., "Investigations of Nearly (net) Zero Energy Residential Buildings in Beijing,” Procedia Eng., vol. 121, pp. 1051-1057, 2015.

[2] M. Noussan, M. Jarre, L. Degiorgis, and A. Poggio, "Data Analysis of the Energy Performance of Large Scale Solar Collectors for District Heating,” Energy Procedia, vol. 134, pp. 61-68, 2017.

[3] Werner Weiss, Monika Spörk-Dür, Franz Mauthner, Solar Heat Worldwide-Global Market Development and Trends in 2016-Detailed Market Figures 2015 (2017 version). http://www.iea-shc.org/solar-heat-worldwide, 2017.

[4] IEA, “IEA-SHC Task 49,” 2016. [Online]. Available: http://task49.iea-shc.org/publications.

[5] M. S. A. Khan, A. W. Badar, T. Talha, M. W. Khan, and F. S. Butt, "Configuration based modeling and performance analysis of single effect solar absorption cooling system in TRNSYS,” Energy Convers. Manag., vol. 157, pp. 351-363, 2018.

[6] B. Tashtoush, A. Alshare, and S. Al-Rifai, "Hourly dynamic simulation of solar ejector cooling system using TRNSYS for Jordanian climate,” Energy Convers. Manag., vol. 100, pp. 288-299, 2015.

[7] F. Bava and S. Furbo, "Development and validation of a detailed TRNSYS-Matlab model for large solar collector fields for district heating applications,” Energy, vol. 135, pp. 698-708, 2017.

[8] W. Kong et al., “An improved dynamic test method for solar collectors,” Sol. Energy, vol. 86, no. 6, pp. 1838-1848, 2012.

[9] W. Kong, Z. Wang, X. Li, X. Li, and N. Xiao, "Theoretical analysis and experimental verification of a new dynamic test method for solar collectors,” Sol. Energy, vol. 86, no. 1, pp. 398-406, 2012.

[10] J. Deng, X. Yang, and P. Wang, "Study on the second-order transfer function models for dynamic tests of flat-plate solar collectors Part I: A proposed new model and a fitting methodology,” Sol. Energy, vol. 114, pp. 418-426, Apr. 2015.

[11] J. Deng, X. Yang, and P. Wang, "Study on the second-order transfer function models for dynamic tests of flat-plate solar collectors Part II: Experimental validation,” Sol. Energy, vol. 141, pp. 334-346, 2017.

[12] J. Deng, Y. Xu, and X. Yang, "A dynamic thermal performance model for fl at-plate solar collectors based on the thermal inertia correction of the steady-state test method," Sol. Energy, vol. 76, pp. 679-686, 2015.

[13] Z. Tian, B. Perers, S. Furbo, and J. Fan, “Analysis and validation of a quasi-dynamic model for a solar collector field with flat plate collectors and parabolic trough collectors in series for district heating,” Energy, vol. 142, pp. 130-138, 2018.

[14] Z. Tian, B. Perers, S. Furbo, and J. Fan, “Annual measured and simulated thermal performance analysis of a hybrid solar district heating plant with flat plate collectors and parabolic trough collectors in series,” Appl. Energy, vol. 205, pp. 417-427, 2017.

[15] Z. Tian, B. Perers, S. Furbo, and J. Fan, "Thermo-economic optimization of a hybrid solar district heating plant with flat plate collectors and parabolic trough collectors in series," Energy Convers. Manag., vol. 165, pp. 92-101, 2018. 
[16] Vela Solaris, "Polysun,” 2018. [Online]. Available: http://www.velasolaris.com/english/home.html.

[17] ScenoCalc, "ScenoCalc - a program for calculation of annual solar collector energy output," 2018. [Online]. Available: https://www.sp.se/en/index/services/solar/ScenoCalc/Sidor/default.aspx.

[18] M. Berberich, "SCFW - SOLAR YIELD PREDICTION TOOL FOR SOLAR DISTRICT HEATING SYSTEMS BASED ON SCENOCALC,” in 5th International Solar District Heating Conference, 2018.

[19] L. Salgado Conrado, A. Rodriguez-Pulido, and G. Calderón, "Thermal performance of parabolic trough solar collectors,” Renew. Sustain. Energy Rev., vol. 67, pp. 1345-1359, 2017.

[20] İ. Halil Y1lmaz and A. Mwesigye, "Modeling, simulation and performance analysis of parabolic trough solar collectors: A comprehensive review,” Appl. Energy, vol. 225, pp. 135174, 2018.

[21] K. S. Reddy, C. S. Ajay, and B. Nitin Kumar, "Sensitivity study of thermal performance characteristics based on optical parameters for direct steam generation in parabolic trough collectors,” Sol. Energy, vol. 169, pp. 577-593, Jul. 2018.

[22] L. Xu et al., "Analysis of the influence of heat loss factors on the overall performance of utility-scale parabolic trough solar collectors,” Energy, Jul. 2018.

[23] Z. D. Cheng, Y. L. He, F. Q. Cui, R. J. Xu, and Y. B. Tao, "Numerical simulation of a parabolic trough solar collector with nonuniform solar flux conditions by coupling FVM and MCRT method,” Sol. Energy, vol. 86, no. 6, pp. 1770-1784, Jun. 2012.

[24] Z. D. Cheng, Y. L. He, and F. Q. Cui, "A new modelling method and unified code with MCRT for concentrating solar collectors and its applications,” Appl. Energy, vol. 101, pp. 686-698, Jan. 2013.

[25] B. Agagna, A. Smaili, and Q. Falcoz, "Coupled simulation method by using MCRT and FVM techniques for performance analysis of a parabolic trough solar collector,” Energy Procedia, vol. 141, pp. 34-38, Dec. 2017.

[26] Z.-D. Cheng, Y.-L. He, K. Wang, B.-C. Du, and F. Q. Cui, “A detailed parameter study on the comprehensive characteristics and performance of a parabolic trough solar collector system,” Appl. Therm. Eng., vol. 63, no. 1, pp. 278-289, Feb. 2014.

[27] M. Shadmehri, H. Narei, R. Ghasempour, and M. B. Shafii, "Numerical simulation of a concentrating photovoltaic-thermal solar system combined with thermoelectric modules by coupling Finite Volume and Monte Carlo Ray-Tracing methods,” Energy Convers. Manag., vol. 172, pp. 343-356, Sep. 2018.

[28] Y.-L. He, J. Xiao, Z.-D. Cheng, and Y.-B. Tao, “A MCRT and FVM coupled simulation method for energy conversion process in parabolic trough solar collector," Renew. Energy, vol. 36, no. 3, pp. 976-985, Mar. 2011.

[29] Z. Wu, S. Li, G. Yuan, D. Lei, and Z. Wang, "Three-dimensional numerical study of heat transfer characteristics of parabolic trough receiver,” Appl. Energy, vol. 113, pp. 902-911, Jan. 2014.

[30] Y. Wang, Q. Liu, J. Lei, and H. Jin, "International Journal of Heat and Mass Transfer Performance analysis of a parabolic trough solar collector with non-uniform solar flux conditions,” Int. J. Heat Mass Transf., vol. 82, pp. 236-249, 2015.

[31] A. S. Tijani and A. M. S. Bin Roslan, "Simulation Analysis of Thermal Losses of Parabolic trough Solar Collector in Malaysia Using Computational Fluid Dynamics," Procedia Technol., vol. 15, pp. 841-848, 2014.

[32] Y. Qiu, M.-J. Li, Y.-L. He, and W.-Q. Tao, "Thermal performance analysis of a parabolic 
trough solar collector using supercritical $\{\mathrm{CO} 2\}$ as heat transfer fluid under non-uniform solar flux,” Appl. Therm. Eng., p. , 2016.

[33] Z. Tian, B. Perers, S. Furbo, J. Fan, J. Deng, and J. Dragsted, “A Comprehensive Approach for Modelling Horizontal Diffuse Radiation, Direct Normal Irradiance and Total Tilted Solar Radiation Based on Global Radiation under Danish Climate Conditions,” Energies, vol. 11, no. 5, p. 1315, May 2018.

[34] Solargis, “Global Solar Atlas.” [Online]. Available: http://globalsolaratlas.info. [Accessed: 20-Apr-2018].

[35] B. Perers, Optical Modelling of Solar Collectors and Booster Reflectors under Non Stationary Conditions. Uppsala: Uppsala University, 1995.

[36] B. Perers, "Dynamic method for solar collector array testing and evaluation with standard database and simulation programs,” Sol. Energy, vol. 50, no. 6, pp. 517-526, 1993.

[37] B. Perers, P. Kovacs, M. Olsson, M. Persson, and U. Pettersson, "A tool for standardized collector performance calculations including PVT,” Energy Procedia, vol. 30, pp. 13541364, 2012.

[38] B. Perers, B. Karlsson, and H. Wallentun, "Simulation and Evaluation for Solar Energy Systems. D20:1990.” Swedish Council for Building Research, 1990.

[39] TRNSYS, “TRNSYS 17 - Volume 7 Programmer’s Guide.” Solar Energy Laboratory, University of Wisconsin-Madison, 2014.

[40] Absolicon Solar Collector AB, “Absolicon Solar Collector AB.” 2018.

[41] SP Technical Research Institute of Sweden, "Test of Solar Collector Thermal Performance and Pressure Drop according to ISO 9806:2013 Ref:6P06089,” 2016.

[42] TRNSYS, “TRNSYS 17.” 2017.

[43] SPF, “SPF,” 2018. [Online]. Available: http://www.spf.ch/Testing.52.0.html?\&L=6.

[44] B. Perers, H. Zinko, and P. Holst, "Analytical Model for the Input Output Energy Relationship.” First EC Conference on Solar Heating, Amsterdam, 1984.

[45] M. Adsten, B. Perers, and E. Wäckelgård, "The influence of climate and location on collector performance," Renew. Energy, vol. 25, no. 4, pp. 499-509, 2002.

[46] S. Keymark, "Solar KeyMark Database.” [Online]. Available: http://www.solarkeymark.dk/CollectorCertificates. [Accessed: 20-Apr-2018]. 


\section{$480 \quad$ Appendix}
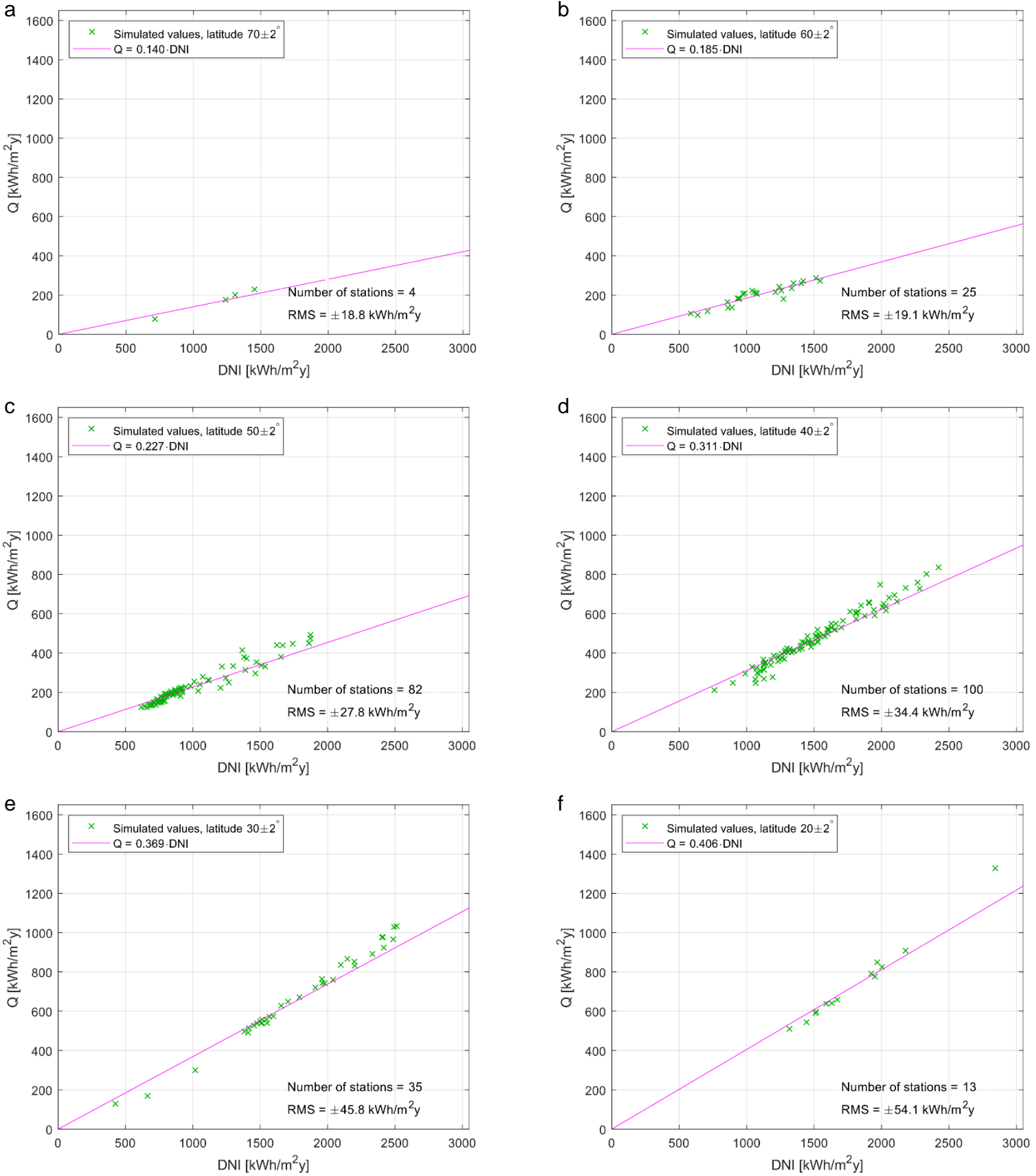

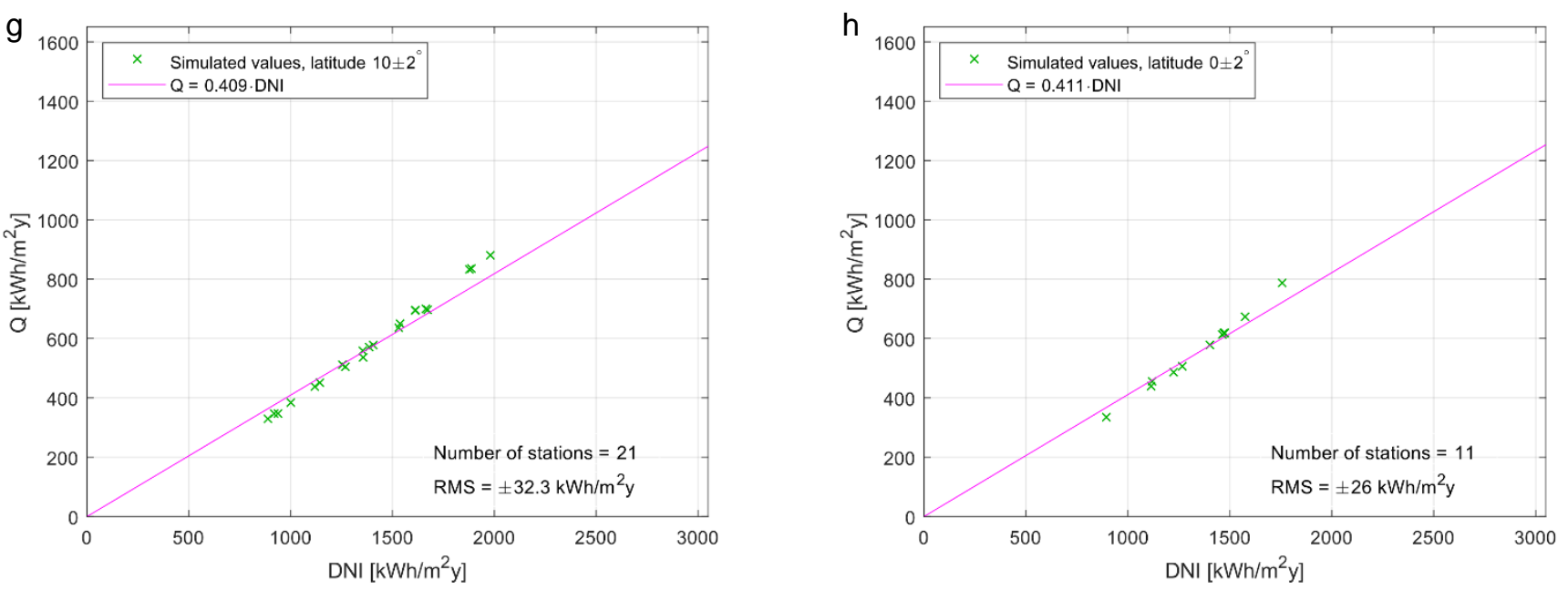

482 Figure 10a-h. Simulated values for annual T160 collector yield compared to DNI around latitudes $70^{\circ}$, $48360^{\circ}, \ldots, 0^{\circ}$. Collector yield simulations based on a mean operating temperature of $160^{\circ} \mathrm{C}$. A linear 484 regression is shown with a magenta line.
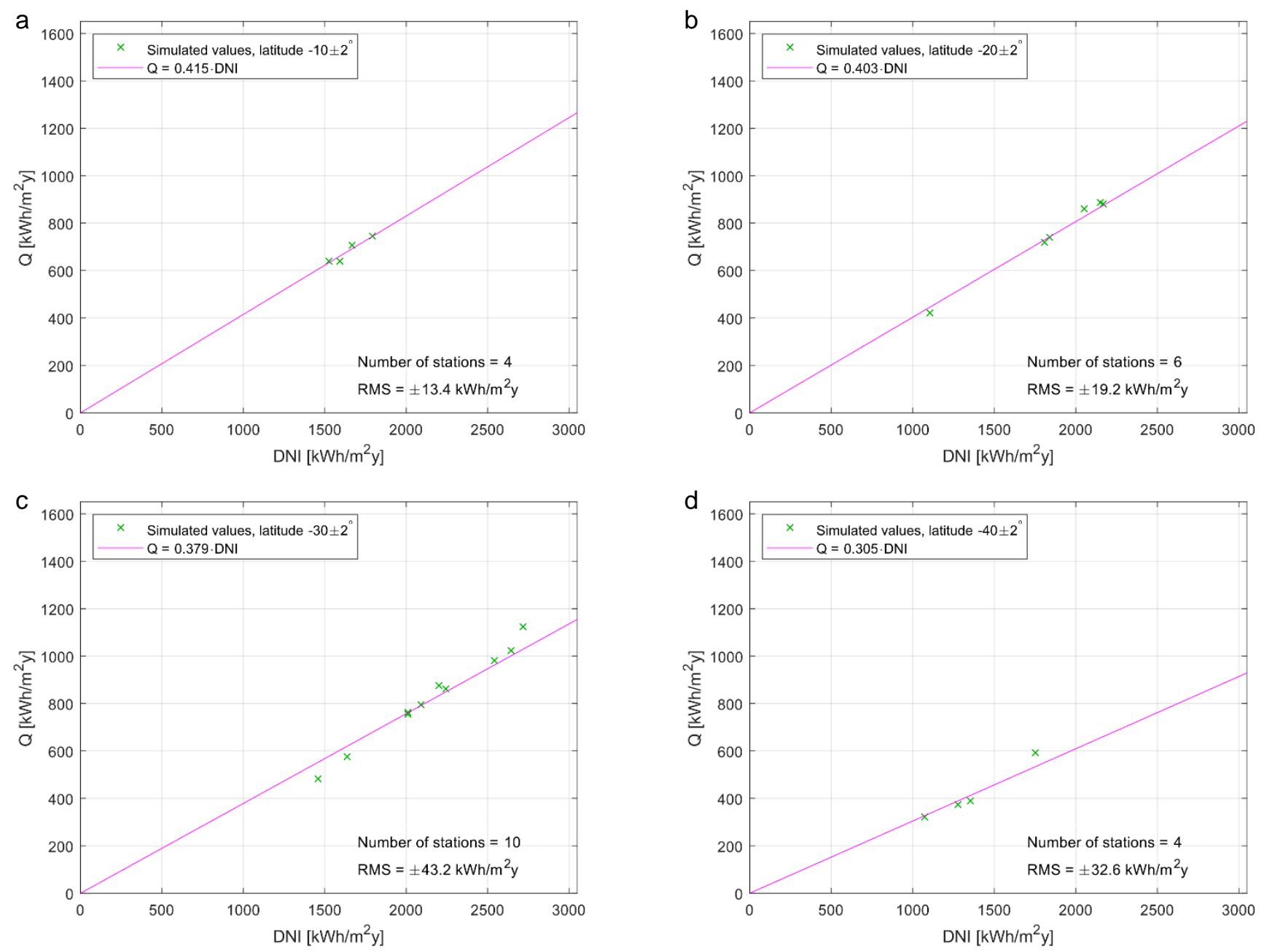


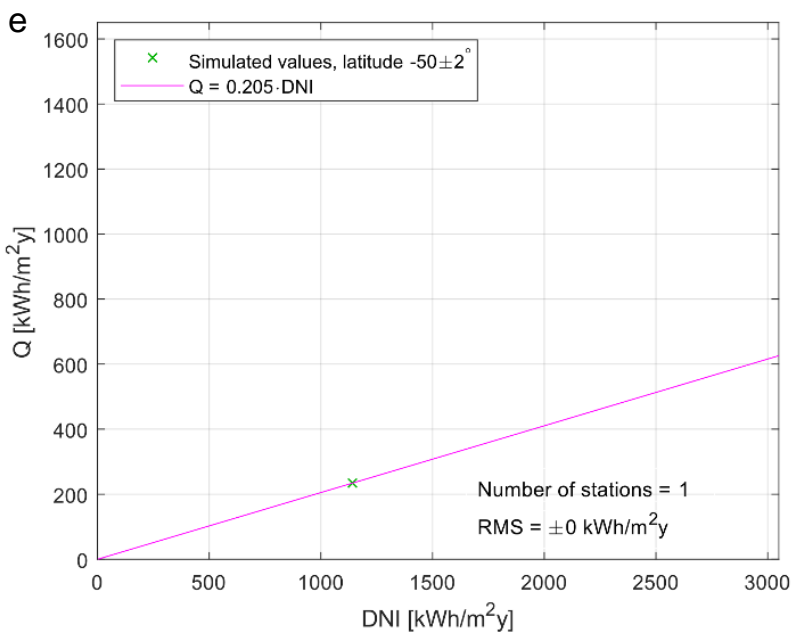

Figure 11a-e. Simulated values for annual T160 collector yield compared to DNI around latitudes $-10^{\circ}$, $-20^{\circ}, \ldots,-50^{\circ}$. Collector yield simulations based on a mean operating temperature of $160^{\circ} \mathrm{C}$. A linear 488 regression is shown with a magenta line.

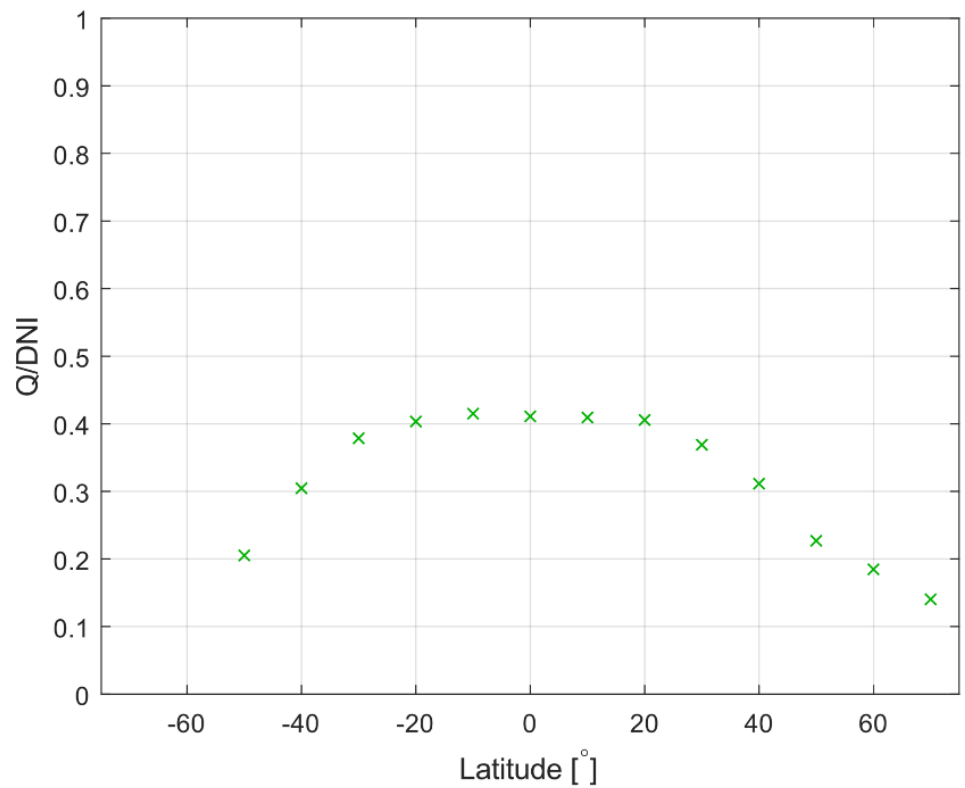

Figure 12. Energy output per DNI plotted against latitude. Collector yield simulations based on a mean operating temperature of $160^{\circ} \mathrm{C}$. 
Table 5. Results and error analysis of the linear models describing annual yield based on annual DNI for a

499 certain latitude and a mean operating temperature, $T_{m}=160^{\circ} \mathrm{C}$. Note that for latitude $-50^{\circ}$ only one climate 500 was simulated.

\begin{tabular}{|c|c|c|c|c|c|c|}
\hline Figure & $\begin{array}{l}\text { Latitude } \\
\left( \pm 2^{\circ}\right)\end{array}$ & $k_{1}$ & $\begin{array}{l}\text { Number of } \\
\text { weather stations }\end{array}$ & $\begin{array}{l}\text { RMS error } \\
{\left[\mathrm{kWh} /\left(\mathbf{m}^{2} \cdot \mathrm{y}\right)\right]}\end{array}$ & $\begin{array}{l}\text { Mean residual } \\
\text { [\%] }\end{array}$ & t-ratio \\
\hline $10 \mathrm{a}$ & 70 & 0,140 & 4 & 18,8 & 12,3 & 22 \\
\hline $10 \mathrm{~b}$ & 60 & 0,185 & 25 & 19,1 & 8,53 & 54 \\
\hline $10 \mathrm{c}$ & 50 & 0,227 & 82 & 27,8 & 8,30 & 86 \\
\hline 10d & 40 & 0,311 & 100 & 34,4 & 5,52 & 150 \\
\hline $10 \mathrm{e}$ & 30 & 0,369 & 35 & 45,8 & 6,26 & 106 \\
\hline $10 \mathrm{f}$ & 20 & 0,406 & 13 & 54,1 & 4,10 & 54 \\
\hline $10 \mathrm{~g}$ & 10 & 0,409 & 21 & 32,3 & 4,56 & 94 \\
\hline $10 \mathrm{~h}$ & 0 & 0,411 & 11 & 26,0 & 3,65 & 76 \\
\hline $11 \mathrm{a}$ & -10 & 0,415 & 4 & 13,4 & 1,64 & 102 \\
\hline $11 b$ & -20 & 0,403 & 6 & 19,2 & 2,35 & 105 \\
\hline $11 \mathrm{c}$ & -30 & 0,379 & 10 & 43,2 & 4,24 & 65 \\
\hline 11d & -40 & 0,305 & 4 & 32,6 & 5,36 & 27 \\
\hline $11 \mathrm{e}$ & -50 & 0,205 & 1 & 0.00 & 0.00 & $\infty$ \\
\hline
\end{tabular}

